\title{
Refugee-focused service providers: Improving the welcome in New Zealand
}

\begin{abstract}
When refugees are resettled into a destination, refugee-focused service providers offer frontline services to ease refugees' experiences of trauma and marginalisation, providing advocacy and welcome through reception processes, translation services and multicultural centres. The degree and effectiveness of welcome given by these service providers is of importance to how quickly refugees feel they belong and can settle in their new society. This paper presents the findings of original research conducted with 34 refugee-focused service providers in New Zealand. Ketso, a creative, participatory tool was used as a community engagement method. The results indicate how these service providers felt the welcome, advocacy and support for refugees could be better organised to support the resettlement process. The barriers and challenges to the provision of welcome are discussed, and priorities identified to improve the refugee resettlement process and outcomes.
\end{abstract}

Keywords: Refugee resettlement; refugee-focused service providers; welcome; advocacy 


\section{Introduction}

Not-for-profits, community groups and NGOs play a crucial role by providing services, connections and advocacy for refugees. ${ }^{1}$ These refugee-focused service providers seek to provide services to meet the needs of refugees who arrive with language issues and in need of medical assistance, housing and long-term support as they adjust to their new environment (Steimel, 2010). Those who are refugees or asylum seekers are forced to flee their home country because they have no other choice, driven by the threat of war, persecution, natural disasters, environmental crises and poverty (Humanities Education Centre, 2009). New Zealand is one of over 120 countries adhering to the 1951 United Nations Convention against torture and other cruel, inhumane treatment or punishment and the International Covenant on Civil and Political Rights allowing for alternative recognition as a protected person (Immigration New Zealand, 2014a). Under the United Nations High Commissioner for Refugees' (UNHCR) annual refugee quota programme, New Zealand opens its doors annually to a quota of approximately 1,000 refugees. From 2005 until 2015, six nationalities of refugees were predominant: Myanmar, Bhutan, Iraq, Afghanistan, Colombia and Sri Lanka (Immigration New Zealand, 2014a). Collaborative approaches between local, national and international bodies (including the New Zealand Government; UNHCR; Red Cross; Amnesty International; refugee-focused service providers, forums and migrant resource centres; among other relevant organisations, agencies and communities) are critical to the development of successful settlement programmes for refugees (ChangeMakers Refugee Forum, 2012; Nawyn, 2011). Such support services enable refugees to cope with the challenges of resettlement and to understand the new culture (Kivunja, Kuyini, \& Maxwell, 2014).

Over a six-week period upon arrival into New Zealand, quota refugees complete an orientation programme at a dedicated facility, the Mangere Refugee Resettlement Centre in Auckland in the North Island of New Zealand, before being resettled into a particular region of the country (West-Newman, 2015). Supported by numerous service providers, they receive information about New Zealand culture, education and laws, health checks, donations of clothing and furnishings, employment programmes to help them find work, volunteer support, English language training, and interpreter services. The New Zealand Settlement

\footnotetext{
${ }^{1}$ Throughout this paper we use the term 'refugee' to denote those people who have entered New Zealand on the refugee quota programme. We recognise the tensions and debates around self-categorisation and identity classifications. Depending on situation and personal preference, alternative terms may include 'former refugee', 'displaced person', 'refugee-background', 'permanent resident' and 'citizen'.
} 
Strategy and National Settlement Action Plan provides a framework for government and volunteer agencies to work together, focusing on issues of self-sufficiency, participation, health and wellbeing, education and housing. The vision is that refugees participate fully and are integrated socially and economically as soon as possible so that they are living independently, exercise the same rights as other New Zealanders and have a strong sense of belonging (Immigration New Zealand, 2017a). Narratives from refugees indicate that they value getting involved in their communities, and helping others alleviates some of the trauma to play a healing role in their lives (Puvimanasinghe, Denson, Augoustinos, \& Somasundaram, 2014).

Previous research shows that most refugees intend to stay in the new society into which they are resettled but report difficulties upon entry, including a lack of awareness of available services, problems finding housing, employment and accessing health care, low selfconfidence, no close friends, poor health, language barriers and discrimination (Quinn, 2014; Sim \& Bowes, 2007). Employment can be a particularly difficult obstacle for refugees because of a low level of English language proficiency and/or a lack of recognition of their previous profession and education (Garrett, 2006; Sienkiewicz, Mauceri, Howell, \& Bibeau, 2013). Refugees are extremely vulnerable due to a combination of language difficulties, previous detention, cultural norms and the trauma of past experiences (Manning \& James, 2011). Furthermore, they have tended to lose family connections by moving and find their lives lack meaning in the new environment (Amnesty International New Zealand, 2014; Guhan \& Liebling-Kalifani, 2011). There is a need for them to feel a sense of belonging to a community in which they can trust and feel included rather than excluded because of cultural differences (Marlowe, 2015; Netto, 2011). As such, there is an urgent call for improved advocacy for this vulnerable population, and greater attention to the human rights of those refugees being settled in New Zealand in the future (Manning \& James, 2011). Further to this, the New Zealand Refugee Resettlement Strategy (Immigration New Zealand, 2014b) has demonstrated a growing awareness that policy and service delivery needs to be underpinned by a human rights-based approach and a "holistic framework" in order to be effective. This would involve bringing together a variety of organisations to provide services and support that embrace the principles of participation, accountability, non-discrimination and empowerment, and that link to the international human rights framework.

The key challenges facing many organisations providing services for refugees' resettlement include cultural diversity, intra- and inter-organisational collaboration, and adopting 
approaches that are participatory. Overcoming these challenges may entail moving from seeing refugees as passive recipients to, instead, social inclusion and promoting refugees as agents whose knowledge informs service providers and contributes to creating effective decisions around their requirements (Jones \& Joseph, 2012; Steimel, 2017). Empowerment is seen as crucial as it enables refugees to gain a sense of control, integration and, importantly, self-efficacy around key aspects of their lives (Laverack \& Wallerstein, 2001). Within this context, the aim of this paper is to understand how the nature and degree of welcome offered by refugee-focused service providers in New Zealand could be better organised. Currently, there are no studies that have sought to determine the nature and degree of welcome for refugees in New Zealand, nor how the welcome provided by refugee-focused service providers could be improved. This paper, therefore, has significance towards improving support services for the resettlement of refugees, both in New Zealand and with lessons for elsewhere. Specifically, findings of this research identified the need for greater collaboration and communication between refugee-focused service providers; increased attention to the notion of welcome and advocacy offered by these providers; and continued efforts to reduce discrimination and negative social dialogue around refugees and to encourage their social inclusion. As such, these findings present important theoretical and practical considerations for the practice of welcome and advocacy that can be used to create a climate of participation that will ultimately support social inclusion.

\section{Literature review}

The continuing psychological impacts of trauma experiences prior to resettlement have been widely discussed in previous refugee studies literature (Davidson, Murray, \& Schweitzer, 2008; Green, 2006; Quinn, 2014; Vincent, Jenkins, Larkin, \& Clohessy, 2013). As such, successful resettlement in a host country is fundamental in terms of the adjustment and integration of refugees. Defining resettlement as "a process during which a refugee, having arrived in a place of permanent asylum, gradually re-establishes the feeling of control over his/her life and develops a feeling that life is back to normal”, Colic-Peisker and Tilbury (2003, p. 62) differentiate between an active and passive resettlement style. In short, the authors describe that, whilst some refugees adopt an active approach to resettlement, aiming to achieve particular goals and having a positive attitude to their migration experience, others follow a passive resettlement style, focusing instead on loss and irreparable status. The 
authors conclude that the ability of refugees to successfully overcome practical and emotional challenges during the resettlement process depends on various factors, including refugees' own resources as well as support services provided upon arrival in the country of resettlement.

A review of previous literature has also shown that media plays a significant role in the representation of the refugee crisis and in the lives of refugees themselves. It is argued that media stories are overtly negative in their portrayal of the refugee crisis, yet they have a significant influence on the formation of public and political attitudes towards refugees (O’Doherty \& Lecouteur, 2007). For example, after September 11 in 2001, the words 'stranger', 'refugee', 'terrorist' and 'outsider' were used more frequently by media, creating a climate of fear (Furedi, 2005; Gale, 2004). West-Newman (2015) argues that a stronger media focus on the positive effects of skilled labour, more diverse societies and cultural learning, and increased awareness, care and concern for refugee experiences, would perhaps shape peoples' opinions differently, potentially decreasing discrimination, racism and violence against refugees.

A country's policies also have an important role to play. New Zealand's Resettlement Strategy plays a critical role (Immigration New Zealand, 2014b). However, several authors have criticised the lack of action taken by the New Zealand government, as well as the lack of financial resources provided, such that support remains underfunded and severely stretched (Woodley \& Williams, 2012). As an approach to successfully supporting refugee resettlement in New Zealand, previous studies have stressed the importance of a human rights-based approach (Bhive.govt.nz, 2006; Manning \& James, 2011). One way of achieving this has been advocated as giving refugees the opportunity for active participation in policy development and service delivery (ChangeMakers Refugee Forum, n.d.; Shaw, 2014). A further suggestion has been to mitigate negative attitudes by adoption of the Māori (indigenous) values of manaakitanga (hospitality) to create a more hospitable reception for refugees (Sibley et al., 2011; West-Newman, 2015). According to Kamri-McGurk (2012, p. 17), "these labels have important implications for how refugees are expected to act and how others are supposed to engage with them".

The practice of welcome has been a recent consideration of the New Zealand government in response to increased global and national anxiety over levels of migration, and alongside negative narratives about migrants and refugees in the media and social discourse. As a 
response, New Zealand Immigration and the Ministry of Business, Innovation and Employment developed the 'Welcoming communities - te waharoa ki ngā hapori' framework (Immigration New Zealand, 2017b). The aim of the initiative is to bring together local government and communities to make the places we love more welcoming to everyone. It is expected that local councils lead the initiative in collaboration with communities in order to advocate the welcome for newcomers. Conversely, previous settlement initiatives in New Zealand have solely focused on support for newcomers rather than mobilising and involving local residents in welcoming refugees and migrants. This new approach "creates bridges between the receiving community and newcomers" (Immigration New Zealand, 2017b, p. 3).

Given its association with hosts and guests/strangers, the concept of welcome is well positioned in previous literature on notions of hospitality (Lynch, 2017). Indeed, previous work by hospitality scholars, Derrida (1997, 1999, 2000), Cornu (2008) and Ben Jelloun (1999), has explored the notion of hospitality as welcome for migrants and refugees. In particular, Derrida's theory (1997) offers the notion of the 'threshold' of hospitality where hospitality may be offered or refuted. In terms of a hospitable welcome, it has been argued that the threshold of hospitality can be viewed in terms of the practice of advocacy or role of the advocate who becomes a voice and source of empowerment for the vulnerable, including protection, care provision and service (Cockburn-Wootten, McIntosh, \& Phipps, 2014). Advocacy can involve working between and with individuals, groups and policy makers to improve conditions. Indeed, with regards to refugee-focused service provision in New Zealand, there is evidence to show that many existing services have been unsuccessful in facilitating refugees to become part of their new community (for example, Woodley \& Williams, 2012).

The lack of success is primarily due to the interventionist approach taken. There are generally two approaches to supporting refugee resettlement - either an interventionist or a social inclusion approach (Colic Peisker \& Tilbury, 2003). An interventionist approach draws on the assumptions of service providers in order to select strategies, typically focused on mental health outcomes, to suit the needs of refugees and which may be misplaced (Murray, Davidson, \& Schweitzer, 2010). An interventionist approach can therefore lead to negative experiences for refugees who have had traumatic previous experiences of authority, intervention and officialdom, and are often distrustful of using support services at all. The social inclusion approach integrates services that develop self-efficacy and empowerment to encourage refugees to become involved in their community and represent their experiences 
and issues. The nature of the welcome provided to refugees and the nature of support provided to assist their resettlement therefore needs careful consideration. In order to understand the practice of welcome and the experiences of refugee-support service providers in New Zealand, our research adopted an inclusive approach, which is outlined below.

\section{Methodology}

The aim of the research was to understand how the nature and degree of welcome offered by refugee-focused service providers could be better organised. In order to tackle this goal, the Ketso method was adopted to bring refugee-focused service providers together in a neutral space to think collaboratively about creative solutions to improve the welcome for refugees being resettled in New Zealand. Initially, an open invitation was distributed to approximately ten key organisations providing refugee support services within the Waikato region, in the North Island of New Zealand, and to some key national organisations. These organisations promoted the invitation amongst their own networks and membership. In total, 35 stakeholders representing 34 organisations participated in the research, including those from government, non-governmental organisations, and organisations providing services for resettlement, ethnic groups, women's groups, employment, policy, funding, advocacy, research, and English language training. Refugee-background participants representing these organisations also took part in the research.

The Ketso method (www.ketso.com) is a facilitated workshop technique. Facilitated by the two authors, who were experienced in the Ketso method, the participants were divided into six groups and seated around six tables, each with their own Ketso workstation. As a method, Ketso does require all participants to be available at the same time and location. This can be a limitation of the method because scheduling diverse stakeholders to be in the same place at the same time for a significant amount of time (about two to three hours) can be difficult. The 35 participants were present in the room for the duration of the three hour session. Ethics approval was sought from participants for the research to take place, and the study was also approved by The University of Waikato Management School's Human Research Ethics Committee.

Originating from the fields of Education and Environmental Studies, Ketso is a portable toolkit that has previously been used in multiple disciplines to create engagement, colearning, co-constructed analysis and collaborative thinking among participants (McIntosh \& 
Cockburn-Wootten, 2016; Tippett, 2013; Tippett \& How, 2011). The method is based on theories of creative thinking (De Bono, 2009), mind mapping (Buzan \& Buzan, 2006), experiential learning (Kolb, 1984) and multiple intelligences (Gardner, 1999), and is aligned with constructionist epistemology. It is designed to unlock participants' creativity for change solutions. As it is based on inclusive and learning philosophies and systems thinking (see Tippett, Handley, \& Ravetz, 2007), it is also designed to allow all members of the session to contribute equally, rather than allowing certain voices to dominate the group.

Ketso enables individuals to contribute their ideas regarding a central problem or question. The central consideration in our research was 'organising the welcome and support for refugees in New Zealand'. Participants identify what actions are working well, what could be improved, the key barriers, and opportunities for the future. The group then discusses those ideas, collaboratively they thematically organise and analyse the points before finally agreeing priority areas for action. As such, the main themes that emerge from the Ketso session are inductively co-created by the participants themselves throughout the session rather than by independent data analysis. A major advantage of the tool is its ability to facilitate both individual ideas as well as group analysis toward a visual plan proposing a solution/action(s). An additional benefit is the enhanced capacity for participants through the exchange of ideas and opportunities to question existing practices. Alternative planning tools such as Community Mapping, Focus Groups and Lego Serious Play can be seen as limiting because they are said to impede mutual learning between participants; do not allow participants to engage in an active or meaningful manner; focus too much on problems and barriers, reducing creative thinking; do not focus on future planning or creative thinking for new solutions; do not innovate or animate the process; nor plan for consensus as a mechanism to achieve development outcomes (McIntosh \& Cockburn-Wootten, 2016).

The session concluded with the facilitators bringing the tables together into a collaborative discussion to list the common themes from the Ketso output displayed at each table (see Table 1), and specifically, to gauge agreement (or otherwise) with respect to their top priorities for action. Once the session was concluded, each table's Ketso output was photographed for accuracy, the data was typed into a Ketso simple Word template (http://ketso.com/resources-downloads/available-resources\#capturing) and returned to the participants for validation. The findings of the Ketso session are presented and discussed below using the data captured from each Ketso workstation and the common themes and action points identified in the concluding collaborative discussion. Whilst the common 
themes were co-created by the participants themselves, for the purposes of this article, the authors synthesised and interpreted the data to elaborate the themes, relationships between the themes and their overall significance in relation to the extant literature (Golden-Biddle \& Locke, 2007).

\section{Findings}

Ketso indicated how the refugee-focused support providers felt the welcome, advocacy and support for refugees could be better organised for greater effect on the lives of refugees to support the settlement process. Overall, the Ketso outputs of the six groups revealed seven key themes. These themes are discussed below and are presented in no particular order of importance. They are defined inductively by the labels given by participants during the Ketso outputs (see Table 1).

- Insert Table 1 about here -

\section{Relationships to challenge discrimination}

Across the six tables, there were common themes identified by participants around the need for greater collaborative relationships between stakeholders to share ideas, strengthen existing resettlement support, tackle support for refugees and, crucially, challenge discrimination. Greater collaboration was equated with a more holistic approach to supporting the refugee resettlement journey, with refugee-focused service providers working together and spreading the word on events and opportunities. Current activities that were viewed as working well included, for example, social soccer groups, which promote appreciation for diversity by encouraging fun, inclusive community engagement through an activity. Participants also identified opportunities to build new partnerships, friendship 'buddy' systems, and to develop more effective communication for awareness around refugee issues. It was felt that there were greater opportunities for refugee-focused service providers to gather together to think through issues, such as through the Ketso process, and that these collaborative relationships could be rewarded by funding agencies. There were no reported barriers stated by participants around building relationships to challenge discrimination. 


\section{Education}

All of the participant groups noted that education for refugees and their children is important for empowering and supporting refugees. Education was generally referred to among participants in relation to formal learning programmes and wider cultural-awareness for both refugees and the host society. Aspects of formal education reported by the participants that are currently working well but could be strengthened included: English language training; work experience opportunities; cultural awareness training; training around understanding business culture in New Zealand; training in Te Reo (Māori language) and tikanga Māori (indigenous) values; career advice; leadership training; and assistance for special needs families. There was also the reported need to provide more training opportunities for volunteers, interpreters and employers.

In terms of educating the wider New Zealand community, participants suggested creating more awareness about refugees and their success stories. Further opportunities were identified by participants around promoting events to celebrate the services that are going well and to develop a greater number of social activities to get people mingling. These initiatives were seen to enhance integration and the celebration of 'sameness' in order to raise greater public awareness about the experiences of refugees. The promotion around these events would also aid in finding people who can help refugees practice their English language. It was also reported that business-orientated social events involving potential employers could help provide opportunities for apprenticeship/internship programmes for refugees. Stronger communication activities were identified in order to create public awareness in the community about the refugee-focused support services that are already in existence, the different providers that offer the support and how to access them, research to ensure programme effectiveness, and greater opportunities for life-long learning.

The barriers identified relating to education were: the lack of awareness and education on cultural differences for both refugees and the host society; language education for refugees; fragmentation of education services and associated funding; and the difficulty in connecting refugees with the wider communities in which they reside.

\section{Resources, policy and service delivery}


All participants saw resourcing as vital to the refugee resettlement process. Across the six tables, there were common references made to the need for greater financial, political and volunteer labour resourcing. Areas of resourcing that could be improved included: consistent funding streams; devolved funding decisions; better housing options; a co-ordinated volunteer network for the refugee community; greater support after the initial three-month volunteer period (perhaps to a five-year support programme); grouping of existing services and partnership funding; greater opportunities for refugee apprenticeships, training and employment; a hub to showcase and support refugee entrepreneurship; more volunteers to help with English language support; a shared database of support received by the refugees; scholarships for refugee-background tertiary students; and research to validate funded programmes. Specific barriers to resourcing included: a lack of funding for social workers and refugee-focused service providers in general; poor housing and employment opportunities; a lack of political will to make policy changes; and a lack of resourcing for driving lessons for refugees.

\section{Understanding refugees' needs}

Participants commonly reported the need to listen, understand and have empathy for the needs of refugees and their children in effectively welcoming them and supporting their resettlement. It was noted that current effective services were those in which staff and/or volunteers listen, talk to, respect, understand, empower, empathise with and help refugees. It was deemed important that services are delivered in the refugees' own language. Hence, there was a commonly held view that more interpreter services could be offered and that it is important to ensure interpreters act ethically and in confidence. There was also a shared view that increased networking between organisations was important for ensuring refugees' needs are heard, implemented and to ensure they are connected with appropriate opportunities. The main barriers identified by the participants in relation to identifying refugees' needs included: language barriers; lack of public awareness and discrimination; and duplication of services.

\section{Empowerment and capacity building}

Empowerment and capacity building for refugees and refugee-background youth were identified as important aspects of refugee resettlement by all the participants because they 
enable hope, independence and the fulfilment of dreams. Empowerment and capacitybuilding were generally aligned with a welcome experience, respect, language support and the achievement of independent living. Some aspects of current services were seen as working well to support refugee resettlement, including start-up projects that met an identified refugee need and developed capacity; providing language support; providing ethnic support; flexibility in the supply of services; providing a range of programmes supported by refugees for refugees; and provision of relevant workshops.

Aspects of capacity building that could be improved included: the need for more programmes for refugee youth and parenting programmes; pathways into employment and work experience services, especially in the rural areas; the need for more volunteers trained in facilitating empowerment; a greater number of interpreters across all services; more vehicles to overcome limitations in public transport infrastructure or to help those refugees living far from bus stops; and offering regular cultural workshops to support awareness of diversity and social inclusion. The barriers to achieving greater capacity building for refugees were noted as: English language barriers; lack of cultural awareness; a fragmented, siloed approach to services; and a lack of resource allocation.

\section{Welcome and nurturing}

This theme relates to the nature and essence of welcome offered to refugees to aid their resettlement into their new community so that they have a place in which they can begin to belong. Participants used phrases to describe the essence of this common theme, including, for example: 'welcoming and friendly'; 'creating warm and welcoming home'; 'smiling, welcoming people'; 'honour and respect each person'; 'having an open mind'; 'listening'; 'cooking'; ‘talking'; ‘having empathy'; ‘connecting'; ‘encourage'; 'help build confidence'; 'building and maintaining relationships'; 'support family and friends'; 'care for people'; 'make refugees feel at home'; 'nurturing'; 'warm fuzzy'. Essentially, the participants shared a common view about the way in which refugees should be welcomed into New Zealand society by communities at large and through the provision of their services and wider communication. The identified barriers with respect to the welcome were the health and family issues of the refugee families themselves, culture shock or hidden prejudice and fear in the wider New Zealand public, and negative media portrayals of the refugee crisis. 


\section{Research and advocacy for change}

The importance of research and advocacy for supported refugee resettlement was reported as a specific theme by five out of the six groups of participants. Participants identified community-based research as able to: open new ideas to help support and advocate for refugees and reduce barriers to resettlement; bring attention to key issues and the need for advocacy; identify adaptation strategies; lobby government for better policies; and validate the effectiveness of current programmes. Building on existing research, it was identified: that there could be a nationwide action-oriented (quantitative) programme of research around key issues; that research should seek to find ways to challenge dominant stereotypes about refugees; and that storytelling through the media might help change public awareness and understanding. It was also felt that advocacy and case management should extend beyond the current 12-month period. The barriers to research and advocacy included: lack of adequate funding for research and advocacy delivery or the political will to fund opportunities; negative portrayals of refugees in the media (the highlighting of bad-news stories); hidden prejudice and fear; and a lack of male voices in refugee research. The significance of the lack of male voices in refugee research is that it misrepresents the diversity of refugees and their experiences, and incapacitates the male voice in decision-making made by organisations on behalf of refugees (Kisiara, 2015).

\section{Priority actions}

When priority actions from each of the six groups were brought together, the facilitators helped the whole group collectively to identify their shared priorities for future action. In view of the respective themes identified by each group, there was a shared priority for participating organisations to further influence policy makers and to make the New Zealand Refugee Resettlement Strategy work, perhaps by means of requesting an evaluation to investigate whether or not the goals have been effectively implemented. A further priority was the need for policies to encourage language development, to prioritise English language learning over employment in relation to support services - especially to learning the English necessary for a higher level of education, and finding volunteers to assist with the fluency of learned English. The need for greater resourcing, especially funding, to assist resettlement was also identified. Collaboration between government departments and NGOs, and the development of a centralised data-sharing system between agencies were also prioritised. 
The host community was also a focus for priority action. Specifically, participants collectively agreed that changing the mind-set of the host community remained as an important priority. Opportunities for positive media campaigns with the right mode and medium were discussed, including the need to showcase positive success stories and, through media content, illustrate the stories of refugees who have made a positive contribution to New Zealand society. In this respect, participants prioritised the need to identify community leaders and role models, and showcase their stories in a positive light. Lastly, participants prioritised the need to increase host community involvement via the employment of refugees and encouraging volunteering.

\section{Discussion of findings}

Three significant findings emerged from this research and are worthy of further discussion. The first significant finding is the need for refugee-focused service providers to collaborate in order to provide effective refugee-support services for resettlement, along with clear communication channels. Communication is often described as an element that holds an organisation together as it enables interaction within the organisations as well as among the external stakeholders and publics (Barker \& Angelopulo, 2005). Collaboration becomes established through elements of trust and commitment as stakeholders interact and begin to feel safe and comfortable (Husain, 2013). For example, if refugees feel safe enough to voice their concerns and access services, then support service providers can start to address their specific needs and reduce the competition and duplication of service provision between themselves in the face of scarce funding. This study has thus illustrated the importance of service providers being able to communicate and work effectively in order to ensure that refugees gain access to information and services that will support them in their resettlement into a new country.

Collaboration and participation were seen by participants as crucial, especially in light of the move by funding agencies to assign resources based on collaborative projects offering a breadth of services rather than individual organisational indicatives (Erden, 2017). In addition, many of the participants identified previous successful partnerships with effective outcomes and thus had developed trusting relationships. Collaboration was seen as one overall practical strategy that could be implemented to address a number of the challenges facing the refugee-focused service providers. For example, during the Ketso discussion, the 
participants realised that some providers had too many volunteers and others required more for particular events. Additionally, some providers had established volunteer management and health and safety policy plans that they were willing to share with others. Some of the health organisations had skills, resources and knowledge that could be collaboratively used. So collaborative pilot projects emerged as one way to share resources, knowledge and people across the different refugee-focused service providers. This collaborative approach would allow the refugee-focused service providers to meet the needs of refugees. It was similarly recognised that collaboration has become essential to co-ordinate services and resources for pathways to employment for refugees. The result has been a longer-term plan involving refugee-focused service providers along with other businesses to develop pathways towards supporting and gaining refugee employment.

A second significant research finding was that the notion and practice of welcome offered by refugee-focused support providers should provide a model for subsequent interactions between host societiesand refugees Participants identified that there need to be practices adopted from non-interventionist actions that draw on the notion of welcome as empathetic, warm and connecting, as developing respectful relationships, trust and involvement and leading to social inclusion. In previous literature this notion of welcome entails "an open door policy and often a warm welcome to users, who are frequently referred to as 'guests' ... minimum of rules ... adopting a 'make a cup of tea first, ask questions later' approach" (Murray \& Johnsen, 2011, p. 328). In the context of New Zealand, it has also been referred to in respect of an indigenous hospitable welcome and the Māori values of manaakitanga (Sibley et al., 2011). Adopting non-interventionist actions involves centring refugees' voices - having them participate in forums and activities organised and run by refugees, in their own spaces, and on topics of their own choosing (Kisiara, 2015). Conversely, as alluded to earlier, Murray and Johnsen (2011) note that organisations tend to respond with direct interventionist measures supported by government policies that endorse "punitive and exclusionary measures" (p. 326). Newly arrived refugees, however, may be reluctant to participate and resistant to these interventionist practices, as these actions may remind them of the trauma and rejection they faced during their previous life struggles (Villa, Gonçalves, \& Villy Odong, 2017). Instead, the refugee resettlement process can be aided by enabling refugees to actively participate in policy development, service delivery and social inclusion activities (Shaw, 2014). 
In this context, previous researchers have proffered the notion of advocacy as important for service provision; that is, that organisations that integrate some form of advocacy in their services create contexts that enable refugees to be involved in the critical framing of issues that relate to their experiences, knowledge and future (Cambridge \& Williams, 2004; Kisiara, 2015). In particular, advocacy has been seen as useful in developing empowerment and capacity building for community groups (Cockburn-Wootten et al., 2014). At its basic level, advocacy has been defined as "speaking up", empowerment, social justice, equity, representation and "to support people who are devalued or discriminated against" (Forbat \& Atkinson, 2005, p. 322). It is seen as a "unique type of relationship" that develops based on trust between the person and the advocate (Henderson \& Pochin, 2001, p. 82). It has been identified as an "effective [process] where people, for whatever reasons, lack the support of a network of friends and contacts to call on upon in times of need" (Forbat \& Atkinson, 2005, p. 323). Advocacy ranges from formal approaches in organisational services such as legal aid, to more informal voluntary approaches. Advocacy can involve working between and with individuals, groups and policy makers to improve conditions, which "points to the critical role objective advocacy can play at certain points in the lives of refugees" (Cambridge \& Williams, 2004, p. 99).

Thirdly, participants felt that in order to aid resettlement and provide a welcome for refugees, both the media and wider community need to be involved in reducing discrimination and the negative social dialogue around refugees. Indeed, negative portrayals of refugees in the media continue to dominate (O’Doherty \& Lecouteur, 2007; West-Newman, 2015). Researchers have argued that there is a need to move beyond frameworks that position refugees as helpless, which "misrepresents the diversity of refugee experiences [and] helps legitimise decision-making [by others] for refugees" (Kisiara, 2015, p. 163). In this research, evidence was identified of the need for positive media portrayals of refugees and the contributions they make to their new communities; greater cultural awareness to support social inclusion; and participation of refugees in policy development, service delivery and social inclusion activities. These findings indicate the important need for greater emphasis on changing public perceptions of refugees, and service provision that entails social inclusion, as also alluded to above. The aims of the recent New Zealand 'Welcoming communities - te waharoa ki ngā hapori' initiative (Immigration New Zealand, 2017b), directed toward making New Zealand communities more welcoming to migrants, seem mostly congruent with these needs. However, the initiative places the responsibility with local government rather than refugee- 
focused service providers per se. Only time will gauge its effectiveness as a welcoming movement. Importantly, however, it promotes the recognition that 'welcoming' activities lead to shared understanding and appreciation of each other, and with that comes positive social, economic and cultural benefits for communities and the nation as a whole.

\section{Conclusion and future research}

There is a call to increase New Zealand's quota of refugees (“Are we doing our bit?," 2017), and the notion of welcome has been determined as an important element in creative, healthy societies (Lynch, 2017). Embedded within the notion of welcome are the particular actions and types of services required to offer welcome and meet the needs of newly arrived refugees. Currently, there are no studies that have sought to specifically determine the nature and degree of welcome needed to support refugee resettlement. To this end, this paper has identified the nature and degree of services currently offered by refugee-focused service providers in order to welcome refugees in New Zealand. These providers identified solutions and practical implications for how this welcome can be better organised for the future.

Specifically, the research revealed key findings around the need for greater collaboration and communication between refugee-focused service providers; increased attention to the notion of welcome and advocacy offered by these providers; and continued efforts to reduce discrimination and negative social dialogue around refugees and encourage social inclusion.

To achieve these outcomes, there is also a need to perhaps address the important issues of underfunding and strategy underpinning the delivery of refugee-focused service provision, and these two priorities were identified by the participants in this study. In short, the study revealed a picture of a fragmented, underfunded approach to the welcome of refugees in New Zealand. Thus, to conclude, this paper calls for continued research in this area to evaluate approaches and funding mechanisms toward a better resourced and coordinated approach to the reception and welcome of refugees by refugee-focused service providers in New Zealand. There is also the need to consider ways to engage with media and lobby government to reflect refugees in a more balanced representation that also highlights their positive contribution to society. We encourage comparisons to be drawn to note implications beyond New Zealand. 


\section{References}

Amnesty International New Zealand. (2014). Refugees and asylum seekers. Retrieved from http://www.amnesty.org.nz/our-work/refugees-asylum-seekers

Are we doing our bit? (2017). Retrieved from http://www.doingourbit.co.nz/p/the-issue.html

Barker, R., \& Angelopulo, G. C. (2005). Integrated organisational communication. Cape Town, South Africa: Juta and Company.

Ben Jelloun, T. (1999). French hospitality: Racism and North African immigrants. New York, NY: Columbia University Press.

Bhive.govt.nz. (2006, June 27). Refugee health and well-being [Speech transcript]. Retrieved September, 2017, from https://www.beehive.govt.nz/speech/refugee-health-and-wellbeing

Buzan, T., \& Buzan, B. (2006). The mind map book. Harlow, England: BBC Active.

Cambridge, P., \& Williams, L. (2004). Approaches to advocacy for refugees and asylum seekers: A development case study for a local support and advice service. Journal of Refugee Studies, 17(1), 97-113.

ChangeMakers Refugee Forum. (2012). 'People with refugee backgrounds can do the job': Refugee-background experiences of employment in Wellington. Retrieved from http://crf.org.nz/sites/default/files/staff/ChangeMakers\%20Employment\%20Research \%20Final_0.pdf

ChangeMakers Refugee Forum. (n.d.). ChangeMakers research. Retrieved September, 2017, from http://crf.org.nz/research programme

Cockburn-Wootten, C., McIntosh, A., \& Phipps, A. (2014). Hospitality as advocacy and vulnerability. Hospitality \& Society, 4(2), 111-114.

Colic Peisker, C., \& Tilbury, F. (2003). "Active" and "passive" resettlement: The influence of support services and refugees' own resources on resettlement style. International Migration, 41(4), 61-91.

Cornu, L. (2008). Trust, strangeness and hospitality. Diogenes, 55(4), 15-26.

Davidson, G. R., Murray, K. E., \& Schweitzer, R. (2008). Review of refugee mental health and wellbeing: Australian perspectives. Australian Psychologist, 43(3), 160-174.

De Bono, E. (2009). De Bono's thinking course. Harlow, England: BBC Active.

Derrida, J. (1997). De L'Hospitalite. Paris, France: Calmann-Levy.

Derrida, J. (1999). Adieu to Emmanuel Levinas. Stanford, CA: Stanford University Press.

Derrida, J. (2000). Hospitality. Angelaki, 5(3), 3-18. 
Erden, O. (2017). Building bridges for refugee empowerment. Journal of International Migration and Integration, 18(1), 249-265.

Forbat, L., \& Atkinson, D. (2005). Advocacy in practice: The troubled position of advocates in adult services. British Journal of Social Work, 35, 321-335.

Furedi, F. (2005). Politics offear: Beyond left and right. London, England: Continuum International.

Gale, P. (2004). The refugee crisis and fear: Populist politics and media discourse. Journal of Sociology, 40(4), 321-340.

Gardner, H. (1999). Intelligence reframed: Multiple intelligences for the $21^{\text {st }}$ century. New York, NY: Basic Books.

Garrett, K. E. (2006). Living in America: Challenges facing new immigrants and refugees

(Report). Retrieved from Robert Wood Johnson Foundation, Lake Snell Perry Mermin/Decision research website:

http://www.rwjf.org/content/dam/farm/reports/reports/2006/rwjfl3807

Golden-Biddle, K., \& Locke, K. D. (2007). Composing qualitative research. Thousand Oaks, CA: Sage Publications.

Green, M. (2006). They think we are nothing: A survey of destitute asylum seekers and refugees in Scotland (Report). Retrieved from Scottish Refugee Council website: http://www.scottishrefugeecouncil.org.uk/search?q=executive+summary

Guhan, R., \& Leibling-Kalifani, H. (2011). The experiences of staff working with refugees and asylum seekers in the United Kingdom: A grounded theory exploration. Journal of Immigrant \& Refugee Studies, 9(3), 205-228.

Henderson, R., \& Pochin, M. (2001). A right result? Advocacy, justice and empowerment. Bristol, England: Policy Press.

Humanities Education Centre. (2009). Refugee footprint. Retrieved from http://www.globalfootprints.org/refugees

Husain, Z. (2013). Effective communication brings successful organisational change. The Business \& Management Review, 3(2), 43-50.

Immigration New Zealand. (2014a). Settlement services we support. Retrieved from https://www.immigration.govt.nz/about-us/what-we-do/our-strategies-andprojects/settlement-strategy/settlement-services-supported-by-immigration-newzealand 
Immigration New Zealand. (2014b). Settlement strategy. Retrieved from https://www.immigration.govt.nz/about-us/what-we-do/our-strategies-andprojects/settlement-strategy

Immigration New Zealand. (2017a). New Zealand refugee resettlement strategy. Retrieved from https://www.immigration.govt.nz/about-us/what-we-do/our-strategies-andprojects/refugee-resettlement-strategy

Immigration New Zealand. (2017b). Welcoming communities - te waharoa ki ngā hapori. Retrieved from https://www.immigration.govt.nz/about-us/what-we-do/welcomingcommunities

Jones, P. A., \& Joseph, R. (2012). Mentoring refugee community researchers in the UK: An empowerment tool? In L. Goodson \& J. Phillimore (Eds.), Community research for participation: From theory to method (pp. 315-330). Bristol, England: Policy Press.

Kamri-McGurk, U. (2012). Resettlement experiences of Burmese women from refugee backgrounds in Wellington, Aotearoa, New Zealand (Master's thesis, Victoria University of Wellington, New Zealand). Retrieved August, 2017, from http://researcharchive.vuw.ac.nz/handle/10063/2588

Kisiara, O. (2015). Marginalized at the centre: How public narratives of suffering perpetuate perceptions of refugees' helplessness and dependency. Migration Letters, 12(2), 162 171.

Kivunja, C., Kuyini, A. B., \& Maxwell, T. (2014). Settlement experiences of African refugees: A case study of the Armidale, Tamworth and Coffs Harbour regions of New South Wales, Australia. Journal of Asian \& African Studies, 49(1), 64-79.

Kolb, D. A. (1984). Experiential learning: Experience as the source of learning and development. Englewood Cliffs, NJ: Prentice-Hall.

Laverack, G., \& Wallerstein, N. (2001). Measuring community empowerment: A fresh look at organizational domains. Health Promotion International, 16(2), 179-185.

Lynch, P. (2017). Mundane welcome: Hospitality as life politics. Annals of Tourism Research, 64, 174-184.

Manning, D., \& James, E. (2011). Refugees and those in need of protection. In M. Bedggood \& K. Gledhill (Eds.), Law into action: Economic, social and cultural rights in Aotearoa New Zealand (pp. 221-241). Wellington, New Zealand: Thompson Reuters.

Marlowe, J. (2015). Belonging and disaster recovery: Refugee-background communities and the Canterbury earthquakes. British Journal of Social Work, 45(1), 188-204. 
McIntosh, A., \& Cockburn-Wootten, C. (2016). Using KETSO for engaged tourism scholarship. Annals of Tourism Research, 56, 148-151.

Murray, A., \& Johnsen, S. (2011). Community hospitality initiatives: 'Make a cup of tea first, ask questions later'. Psychodynamic Practice, 17(3), 325-329.

Murray, K. E., Davidson, G. R., \& Schweitzer, R. D. (2010). Review of refugee mental health interventions following resettlement: Best practices and recommendations. American Journal of Orthopsychiatry, 80(4), 576-585.

Nawyn, S. J. (2011). 'I have so many successful stories': Framing social citizenship for refugees. Citizenship Studies, 15(6-7), 679-693.

Netto, G. (2011). Identity negotiation, pathways to housing and "place": The experience of refugees in Glasgow. Housing, Theory \& Society, 28(2), 123-143.

O'Doherty, K., \& Lecouteur, A. (2007). “Asylum seekers”, "boat people,” and "illegal immigrants": Social categorisation in the media. Australian Journal of Psychology, $59,1-12$.

Puvimanasinghe, T., Denson, L. A., Augoustinos, M., \& Somasundaram, D. (2014). “Giving back to society what society gave us": Altruism, coping, and meaning making by two refugee communities in South Australia. Australian Psychologist, 49(5), 313-321.

Quinn, N. (2014). Participatory action research with asylum seekers and refugees experiencing stigma and discrimination: The experience from Scotland. Disability \& Services, 29(1), 58-70.

Shaw, S. A. (2014). Bridge builders: A qualitative study exploring the experiences of former refugees working as caseworkers in the United States. Journal of Social Service Research, 40(3), 284-296.

Sibley, C. G., Stewart, K., Houkamau, C., Manuela, S., Perry, R., Wootton, L. W., Harding, J. F., Zhang, Y., Sengupta, N., Hoverd, W. J., West-Newman, T., \& Asbrock, A. (2011). Ethnic group stereotypes in New Zealand. New Zealand Journal of Psychology, 40(2), 25-36.

Sienkiewicz, H. C., Mauceri, K. G., Howell, E. C., \& Bibeau, D. L. (2013). Untapped resources: Refugee employment experiences in Central North Carolina. Work, 45(1), $17-24$.

Sim, D., \& Bowes, A. (2007). Asylum seekers in Scotland: The accommodation of diversity. Social Policy \& Administration, 41(7), 729-746.

Steimel, S. J. (2010). Dialectic tensions experienced by resettled Sudanese refugees in mediating organizations. International Journal of Communication, 4, 117-138. 
Steimel, S. J. (2017). Negotiating refugee empowerment(s) in resettlement organizations. Journal of Immigrant \& Refugee Studies, 15(1), 90-107.

Tippett, J. (2013). Creativity and learning - participatory planning and the coproduction of local knowledge. Town \& Country Planning, 82(10), 439-442.

Tippett, J., Handley, J. F., \& Ravetz, J. (2007). Meeting the challenges of sustainable development - a conceptual appraisal of a new methodology for participatory ecological planning. Progress in Planning, 67(1), 9-98.

Tippett, J., \& How, F. (2011). Ketso guide. Manchester, England: Ketso.

Villa, S., Gonçalves, P., \& Villy Odong, T. (2017). Understanding the contribution of effective communication strategies to program performance in humanitarian organizations. Journal of Humanitarian Logistics and Supply Chain Management, $7(2), 126-151$.

Vincent, F., Jenkins, H., Larkin, M., \& Clohessy, S. (2013). Asylum-seekers' experience of trauma-focused cognitive behaviour therapy for post-traumatic stress disorder: A qualitative study. Behaviour \& Cognitive Psychotherapy, 41(5), 579-593.

West-Newman, C. L. (2015). Changing attitudes: What if refugee lawyers and Maori wrote New Zealand's asylum seeker and refugee policy? New Zealand Sociology, 30(2), 1025.

Woodley, A., \& Williams, L. (2012). Funded services to migrants and refugees in Auckland. Auckland, New Zealand: Auckland Council. Retrieved from http://temp.aucklandcouncil.govt.nz/EN/planspoliciesprojects/reports/technicalpublica tions/Documents/fundedservicestomigrantsandrefugeesinauckland.pdf 
Table 1. Ketso output: Key common themes identified by participants.

\begin{tabular}{|c|c|}
\hline Common theme & Themes identified by the six tables \\
\hline $\begin{array}{l}\text { 1. Relationships to } \\
\text { challenge } \\
\text { discrimination }\end{array}$ & $\begin{array}{ll}\text { - } & \text { Relationships challenging discrimination (Table 1) } \\
\text { - } & \text { Networking and connections (Table 2) } \\
\text { - } & \text { Awllaboration (Table 3) } \\
\text { - } & \text { Creating opportunities (Table 5) } \\
\text { - } & \text { Networking (Table 6) }\end{array}$ \\
\hline 2. Education & $\begin{array}{l}\text { - } \quad \text { Understanding clients' needs (Table 1) } \\
\text { - } \quad \text { Community education (Table 2) } \\
\text { - } \quad \text { Education (Table 3) } \\
\text { - } \quad \text { Creationg (Table 4) } \\
\text { - } \quad \text { Enabling (Table 6) }\end{array}$ \\
\hline $\begin{array}{l}\text { 3. Resources, policy and } \\
\text { service delivery }\end{array}$ & $\begin{array}{ll}\text { - } & \text { Resources and capacity coordination (service delivery) (Table 1) } \\
\text { - } & \text { Money / government policy (Table 2) } \\
\text { - } & \text { Resources (Table 3) } \\
\text { - } & \text { Creating opportunities (Table 5) } \\
\text { - } & \text { Money / funding (Table 6) } \\
\text { - } & \text { Organisational development and policy (Table 6) } \\
\end{array}$ \\
\hline $\begin{array}{l}\text { 4. Understanding clients' } \\
\text { needs }\end{array}$ & $\begin{array}{ll}\text { - } & \text { Understanding clients' needs (Table 1) } \\
\text { - } & \text { English language (Table 2) } \\
\text { - } & \text { Education (Table 3) } \\
\text { - } & \text { Help and support (Table 4) } \\
\text { - } & \text { Doing (Table 6) }\end{array}$ \\
\hline $\begin{array}{l}\text { 5. Empowerment and } \\
\text { capacity building }\end{array}$ & $\begin{array}{l}\text { - } \quad \text { Empowerment and capacity building (Table 1) } \\
\text { - } \quad \text { Community education (Table 2) } \\
\text { - } \quad \text { Help and support (Table 4) } \\
\text { - } \quad \text { Empowerment (Table 5) } \\
\text { - } \quad \text { Enabling (Table 6) }\end{array}$ \\
\hline 6. Welcome and nurturing & $\begin{array}{ll}\text { - } & \text { Understanding clients' needs (Table 1) } \\
\text { - } & \text { Networking and connections (Table 2) } \\
\text { - } & \text { Warm fuzzy nurturing (Table 3) } \\
\text { - } & \text { Belonging (Table 4) } \\
\text { - } & \text { Communication (Table 5) } \\
\text { - } & \text { Values (Table 6) } \\
\end{array}$ \\
\hline $\begin{array}{l}\text { 7. Research and advocacy } \\
\text { for change }\end{array}$ & $\begin{array}{l}\text { - } \text { Research and advocacy for change (Table 1) } \\
\text { - } \text { Generational attitude changes (Table 2) } \\
\text { - } \text { Resources (Table 3) } \\
\text { - Advocacy (Table 4) } \\
\text { - Advocacy (Table 6) }\end{array}$ \\
\hline
\end{tabular}

